\title{
Retrato da poesia contemporânea de Ricardo Domeneck quando em deslocamento com o modernismo
}

\author{
Luis Henrique Garcia Ferreira* \\ Luana Signorelli Faria da Costa**
}

\begin{abstract}
Resumo
Propõe-se analisar o poema contemporâneo Retrato do artista quando Meridiano de Greenwich, do escritor Ricardo Domeneck, presente no livro Sons: Arranjos: Garganta (DOMENECK, 2009). A partir de uma leitura interpretativa, pretende-se abordar o fértil diálogo que o poema estabelece com representantes do modernismo brasileiro, como Carlos Drummond de Andrade, mas também com representantes do modernismo internacional, especialmente com James Joyce. Não obstante, objetiva-se investigar os diversos efeitos de deslocamento que o texto provoca no leitor, entre os quais os sintáticos, os semânticos e os visuais. Argumenta-se que o fruidor precisa relativizar instrumentos interpretativos convencionais para atar os referentes ambíguos da escrita, permeada pelo caráter autobiográfico.
\end{abstract}

Palavras-chave: Poesia contemporânea. Deslocamento. Modernismo.

\footnotetext{
* Universidade Federal do Paraná/ Universidade de Campinas (UFPR/UNICAMP). Doutorando em estudos literários/mestrando em teoria e história literária. Pesquisador. ORCID: https://orcid.org/0000-0002-0974-3148.

** Universidade de Campinas (UNICAMP). Doutoranda em teoria e história literária. Professora. ORCID: https://orcid.org/00000003-2293-6806
} 


\title{
Portrait of Ricardo Domeneck's \\ Contemporany Poetry as on The Move With the Modernism
}

\begin{abstract}
It is proposed to analyze the contemporary poem "Portrait of the artist when Meridian of Greenwich" by writer Ricardo Domeneck, present in the book "Sons: Arranjos: Garganta" (DOMENECK, 2009). From an interpretive reading, it is intended to approach the fertile dialogue that the poem establishes with representatives of Brazilian modernism, such as Carlos Drummond de Andrade, but also with representatives of international modernism, especially with James Joyce. Nevertheless, the objective is to investigate the various displacement effects that the text provokes in the reader, including syntactic, semantic and visual effects. It is argued that the user needs to relativize conventional interpretive instruments to tie the ambiguous referents of writing, permeated by the autobiographical character.
\end{abstract}

Keywords: Contemporary poetry. Displacement. Modernism.

Recebido em: 28/09/2021 // Aceito em: 18/12/2021. 
O título do poema Retrato do artista quando Meridiano de Greenwich, presente no terceiro livro de poemas Sons: Arranjos: Garganta do poeta brasileiro contemporâneo Ricardo Domeneck (2009) remete a outra obra, de outro gênero, de outro autor, de outra época. Trata-se de Um retrato do artista quando jovem ([1916]/2016), ${ }^{1}$ do modernista James Joyce. Esse romance de formação narra os passos de Stephen Dedalus, alter ego do autor, desde a sua infância até os primeiros passos em busca da emancipação artística. Nesse sentido, a autobiográfica obra do irlandês indica uma possibilidade de leitura para o poema do brasileiro, que versifica uma experiência amorosa homoerótica importante na construção do eu-lírico, em uma espécie de "poema de formação". Assim, essa paródia do romance de Joyce se torna o ponto de ignição de um diálogo multifacetário que se estende às gerações modernistas brasileiras, se posicionando em uma margem tênue de resgate e reelaboração dos movimentos.

Além de autobiográfico e plurilíngue, o poema do paulista de Bebedouro, atualmente radicado na Alemanha, também se aproxima da deslizante escrita joyceana por sua ambiguidade e inversão de conceitos tradicionais. Esse efeito de texto e essa inversão do cânone também estabelece uma relação intertextual com diversos momentos do modernismo brasileiro, a exemplo de Oswald de Andrade. Os deslocamentos vão desde as funções morfológica, sintática e semântica até as alternâncias do eu-lírico entre a primeira e a terceira pessoas. A primeira pessoa revela questões sentimentais, muitas vezes mascaradas pelo ultraje cientificista da terceira. Destaca-se também o deslocamento estrutural dos versos, criando uma nova ordem (geo)gráfica para o poema. Dessa forma, não obstante a inspiração em Joyce, a

1 A data entre colchetes indica o ano de publicação original da obra, que somente será indicada em primeira citação neste texto. Nas seguintes, será registrada apenas a data da edição consultada pelos autores. 
escrita também possibilita um profícuo diálogo com outras obras e autores, especialmente do modernismo (em sentido amplo e plural) e do concretismo brasileiros. Segue a transcrição do poema, após a qual procede-se à análise.

Retrato do artista quando

Meridiano de Greenwich

o processo inclui ou

não a conclusão, ele pergunta, a

12 de novembro de 2004,

dia livre, calmo;

isto quer dizer: sem

ocupações, sem precedências,

“... donc, quis'émiette à mesure qu'il se forme":

se toda hipótese

do dia seguinte

desenrola-se

a partir de hoje

(querer dizer e dizer)

erguer meus braços, erguer

sua vontade

até a minha boca,

onde a destreza

se não sou capaz

de invocar

meu querer

como

a indigestão

mas ele

convoca minha vontade

com a

diligência da querência

ao gado:

meu desejo a

causa, o meio, o

objetivo? 


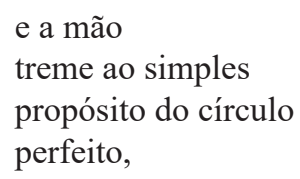

onde você estacionou, a porta talvez abrisse, não houvesse tantas chaves.

$\S \S \S$

causa e ausência:

se se

espera da

voz o centro

da

garganta

e meu sexo

ergue-se

num esfregar de dedos

a Galileu devo

o deslize

do cerne

como núcleo,

a Wittgenstein agradeço

a seca do sêmen

do dicionário

como semântica,

eco da fonte do eco

este desassossego

fora de lugar,

o tremor da língua

e este ar distraído

pulmões adentro

sem resistência, 
esta passividade aérea que

permite

a rotação, a translação

mas

não

o uso das condições

que deslocam a

fome

a cada

"você está com fome?"

se

da fome

sabe a subnutrição do bulímico,

e quando pensa-se poder ao menos

confiar na assistência da

superfície,

contrai-se escabiose

(e as erupções da pele

lembram-me da nostalgia

do cíclico)

$\S \S \S$

mas quis dizer

a interrupção e

confundi-me na

expectativa do

constante jamais

atingido

e acredito poder

prever suas intenções

no escuro

como

pênis e ânus

se há conformidade, 
desejo,

requer-se

rigidez e impulso

e a importância

está no ambiente

como só naquele

momento

o seu "estimo-te

muitíssimo"

pôde causar tamanho

estrago

nos valores

do meu mercado

interno,

ao

perguntar-se a cada

manhã

quais as estimativas

do meu lucro, da

minha perda

e quando ele disse "deve acabar logo"

não soube se o barulho

do quarto

ao lado, a dor do

membro ao lado, a

insônia do amante

ao lado ou o prejuízo

de minhas ilusões

de centro

(DOMENECK, 2009, p. 63-67).

Logo no início, Domeneck faz do próprio título um dístico (estrofe com dois versos), quebrando o sintagma em duas partes: "Retrato do artista quando" + "Meridiano de Greenwich". 
Observa-se uma inversão lógica, pois o que ocupa a segunda posição no sintagma não é um adjetivo ("jovem", no romance de Joyce), mas, sim, um substantivo: "Meridiano de Greenwich", uma linha imaginária utilizada na geografia para separar o mundo em duas partes: Ocidente e Oriente. Assim, o "Meridiano" de Domeneck faz do título a primeira estrofe do poema. Portanto, já no seu primeiro encontro com a escrita, o leitor é deslocado de sua zona de conforto. Ainda no título, o poema continua esse deslocamento, pois se o poeta tivesse utilizado o título do romance tal qual ele já existe, haveria um decassílabo: "Re-trato-deum-ar-tis-ta-quan-do-JO-vem" (10 sílabas poéticas, sendo que "deum" representa uma elisão). Isso, se for retirado o artigo indefinido "um" do sintagma, a exemplo do que fez Domeneck. A omissão do artigo indefinido faz com que o poema saia da indeterminação rumo à determinação (precisão geográfica). A inclusão de um termo da geografia também remete ao cientificismo, vertente literária presente na prosa naturalista do século XIX e na poesia pré-modernista do início do século XX.

Fazendo-se a escansão do título, tem-se: "Re-tra-todeum-ar-tis-ta-QUAN-do" (8 sílabas poéticas, distantes do verso clássico ou tradicional). O segundo verso traz ainda mais surpresas em "Greenwich". Sabe-se que a separação silábica do inglês não corresponde à do português. Portanto, é possível fazer duas análises diferentes para o mesmo verso. Isto é, Domeneck é capaz de provocar ambiguidade até mesmo na métrica, normalmente o elemento de maior precisão na análise poética. Ademais, a métrica do poema é irregular, indo de versos mais longos a outros monossilábicos, como em "da" (v. 42), "mas" (v. 66), "não" (v. 67), "se" (v. 73) e "ao" (v. 111). Esses conectivos atuam como uma ponte entre os outros versos, lembrando 
a função da ligadura na conexão das notas musicais. Um dos versos mais longos está em francês, cuja separação silábica também difere da do português: "donc,-qui-s'é-miet-te-à-mesure-qu'il-se-FOR-me" (11 sílabas poéticas).

A transformação de nomes e títulos preexistentes em versos perfeitamente metrificados já foi usada por outros escritores, especialmente por modernistas. Por exemplo, a poetisa brasileira Cecília Meireles, em seu livro Romanceiro da Inconfidência ([1953]/2015), usa nomes próprios como versos já prontos: "To-más-An-tô-nio-Gon-ZA-ga" (7 sílabas poéticas) e "Joa-quim-Jo-sé-da-Sil-va-Xa-vi-ER" (10 sílabas poéticas). E, quando a métrica não coincide exatamente, ela insere antes do nome próprio um pronome de tratamento que antes não existia: "Do-na-Bár-ba-raE-lio-DO-ra" (7 sílabas poéticas). Cecília Meireles integra a vertente do Neossimbolismo, junto com Vinicius de Moraes e Murilo Mendes, tendo resgatado aspectos do movimento literário do Simbolismo como a música, temática importante também para Domeneck, conhecido por ser um dos representantes da poesia sonora.

Visualmente, o poema não segue modelos convencionais, articulando-se com as experiências poéticas que, desde Um lance de dados (2017), lançado pela primeira vez na revista Cosmópolis em 1897, fazem do branco da página um dos elementos constitutivos do poema. Várias estrofes deslizam como ondas (sonoras?) pelo espaço-texto, sendo o primeiro verso bem alinhado à direita e os seguintes descendo em forma de cascata em uma espécie de dégradé. Aliás, por mais irregular que o poema possa parecer, alguns alinhamentos coincidem perfeitamente, seja na palavra que começa o verso, seja na que o termina. O eu-lírico brinca com os espaços preenchidos e o 
branco da página, como se escrevesse em uma partitura vazia (um pentagrama), alternando pausas com notas musicais.

$\mathrm{O}$ segundo verso indica a presença do prosaísmo por meio do discurso direto (não convencional, pois está sem pontuação), inferível pelo verbo dicendi em "ele pergunta" (v. 02) no presente. Nesse sentido, há um eu-lírico que inicialmente se assemelha a um narrador que expõe os fatos enquanto eles acontecem, o que indica prosaísmo (técnica amplamente usada na poesia modernista, especialmente na primeira geração), dialogando com o romance ao qual o título do poema alude. Outra associação a gêneros literários pode ser feita a partir do verso "12 de novembro de 2004" (v. 03), que lembra a estrutura de um diário, e remete ao hibridismo técnico também característico do modernismo e da odisseia de estilos presente na obra de Joyce. Outro exemplo no qual pode ser observada a aproximação de uma data específica com a invocação de uma memória afetiva é evidenciada no Quadro 1:

\section{Quadro 1 - Comparação entre versos de Ricardo}

Domeneck e Oswald de Andrade

\begin{tabular}{|l|l|}
\hline \multicolumn{1}{|c|}{ RICARDO DOMENECK } & \multicolumn{1}{c|}{ OSWALD DE ANDRADE } \\
\hline $\begin{array}{l}\text { 12 de novembro de 2004, } \\
\text { dia livre, calmo; } \\
\text { isto quer dizer: sem } \\
\text { ocupações, sem precedências [...] }\end{array}$ & $\begin{array}{l}\text { 3 de maio } \\
\text { Aprendi com meu filho de dez anos } \\
\text { Que a poesia é a descoberta } \\
\text { Das coisas que eu nunca vi } \\
\text { (ANDRADE, 1971. p. 104) }\end{array}$ \\
\hline
\end{tabular}

Fonte: Elaborado pelos autores (2021).

Depois, em "donc, quis'émiette à mesure qu'il se forme" (v. 07), há uso de discurso direto convencional, com aspas, configurando uma citação. $\mathrm{O}$ já citado estrangeirismo é um verso em francês cuja tradução é: "portanto, que se desintegra à medida 
que se gradua". Ou seja, além de prosaísmo e estrangeirismo, o verso também traz ao leitor o modus operandi da escrita utilizada no próprio poema, que também passa por processos de desintegração. Verifica-se então organicidade entre forma e conteúdo, o que mais uma vez nos remete a Joyce, mas dessa vez ao seu último livro, o (des)epificante épico modernista Finnegans Wake ([1939/1992), cuja escrita, segundo Samuel Beckett "não é sobre alguma coisa; é a coisa em si [...]" (BECKETT, 1992, p. 331, grifo nosso). A poética de Domeneck também dialoga com o poema Vasos de Benedicto Ferri de Barros, escritor da transição da terceira geração modernista para a literatura contemporânea.

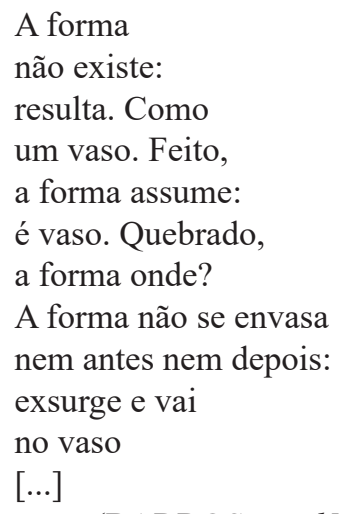

(BARROS apud MOISÉS, 2013, p. 195).

Adiante, o eu-lírico emprega o verbo "desenrola-se" (v. 10) e "hipótese" (v. 08) também. É possível falar de um poema objetivo, ou que pelo menos procura controlar o aspecto subjetivo em um simulacro de objetividade. Mas a técnica não é só científica, como também linguística. É onde reside a diferença entre o verbo e a locução verbal: "querer dizer e dizer" (v. 12), que está entre parênteses, parecendo indicar a intromissão de outra voz no poema. Novamente, há um aspecto modernista, o da polifonia, o qual nos remete ao outro épico modernista de 
Joyce, o polifônico Ulysses ([1922]/2012). O uso da locução verbal em detrimento do verbo reside na mediação: "dizer" é concretizar o ato de falar, enquanto "querer dizer" é a pretensão de falar, não necessariamente dizer. Tome-se como exemplo este verso de Manuel Bandeira, em seu poema Belo belo presente em Estrela da vida inteira: "Quero a delícia de poder sentir as coisas mais simples!". (BANDEIRA, 1966, p. 165, grifos nossos). O sentido de "poder sentir" não é o mesmo de "sentir" diretamente. Ou seja, quantos mais verbos houver na locução verbal, mais mediações existirão, potencializando a ambiguidade ao distanciar o núcleo verbal de um eventual sentido denotativo.

Continuando, o "dia seguinte" (v. 09) do eu-lírico "desenrola-se" (v. 10) sucessivamente, indicando o ciclo da passagem dos dias. O homem moderno e contemporâneo, ou mesmo personagens da literatura modernista, como o personagem Leopold Bloom de Ulysses, muitas vezes tem uma rotina mecânica e enfadonha. Essa crítica também está no poema O elefante (Quadro 2), de Carlos Drummond de Andrade, presente em A rosa do povo ([1945]/2012):

\section{Quadro 2 - Comparação entre versos de Ricardo Domeneck e Carlos Drummond de Andrade}

\begin{tabular}{|l|l|}
\hline \multicolumn{1}{|c|}{ RICARDO DOMENECK } & \multicolumn{1}{|c|}{$\begin{array}{c}\text { CARLOS DRUMMOND DE } \\
\text { ANDRADE }\end{array}$} \\
\hline & \multicolumn{1}{c|}{$\begin{array}{l}\text { E todo seu conteúdo } \\
\text { se toda hipótese } \\
\text { do dia seguinte } \\
\text { desenrola-se } \\
\text { a partir de hoje }\end{array}$} \\
& $\begin{array}{l}\text { De pluma, de carícia } \\
\text { Jorra sobre o tapete }\end{array}$ \\
& Qual mito desmontado \\
& Amanhã recomeço \\
\hline
\end{tabular}

Fonte: Elaborado pelos autores (2021). 
Na segunda estrofe, o eu-lírico insiste em usar verbos no infinitivo, embora não mais conjugados no presente do indicativo como na primeira estrofe. Agora, tem-se: "erguer meus braços, erguer" (v. 10). Essa noção de "erguer" é formativa, o que alude ao romance de formação que serviu de inspiração para o título do poema, mas também é ambígua, pois não são só os braços que se erguem; pode-se inferir que também o membro sexual se eleva, pelo que segue: "sua vontade / até a minha boca" (v. 14-15). Nessa estrofe, nota-se pela primeira vez o eu-lírico adotando a primeira pessoa do singular, para falar de suas próprias experiências. $\mathrm{O}$ poema técnico desloca-se para a lírica sentimental, como se nota pela nominalização do verbo no infinitivo: "meu querer" (v. 19). Esse querer do eu-lírico dialoga com a vontade do outro: "sua vontade" / "meu querer". O verbo "querer" transforma-se no substantivo "querência". Há inclusive a invasão de uma rima interna nesse verso branco: "diligência da querência" (v. 25). Rima interna é quando as palavras ecoam não apenas no fim do verso, como também no meio dele. Então, o poema de versos brancos (sem rima tradicional) é "invadido" pela rima, resistindo liricamente, mesmo que em seu plano interno.

Ainda na mesma estrofe, observa-se mais um ponto estrutural importante: o uso de conectivos. Só nessa estrofe, há o pronome relativo "onde": "onde a destreza" (v. 16); a conjunção integrante condicional "se": "se não sou capaz" (v. 17); a preposição que serve como regência nominal: "capaz / de invocar" (v. 18) - com mais um verbo no infinitivo, "invocar" -; e a conjunção "como": "como a indigestão" (v. 20-21). Aliás, essa última palavra gera ambiguidade, pois pode indicar apenas a função conectiva com o termo subsequente "indigestão", ou então uma conotação sexual do verbo "comer". 
Logo a seguir, esse visceralismo é mesclado a uma análise objetiva: "meu desejo a / causa, o meio, o / objetivo?”. Há enjambement (do francês, emperneamento, o desdobramento do poema em pernas, ramificando-se) quando os substantivos são separados de seus artigos definidos: "a causa" (v. 28) apenas e "o objetivo" (v. 29).

A mesma mão que escreve também treme de desejo, de ansiedade, de impaciência. Os braços estão erguidos, assim como o membro. Tanto o amor quanto a escrita são o "propósito do círculo / perfeito" (v. 32-33), mais uma vez havendo enjambement entre o substantivo e o adjetivo. Novamente, o pronome relativo "onde": "onde você estacionou" (v. 34). "Estacionar" é potencialmente ambíguo, pois pode se remeter ao carro parado ou ao efeito de paralisação, inércia. Ou ainda ao momento de suspensão no relacionamento erótico. Em todo caso, há alusão a chaves, como símbolo do deciframento. Podese invocar Carlos Drummond de Andrade novamente, dessa vez com seu poema A procura da poesia, presente em A rosa do povo (Quadro 3).

\section{Quadro 3 - Comparação entre versos de Ricardo}

Domeneck e Carlos Drummond de Andrade

\begin{tabular}{|l|l|}
\hline \multicolumn{1}{|c|}{ RICARDO DOMENECK } & \multicolumn{1}{c|}{$\begin{array}{c}\text { CARLOS DRUMMOND DE } \\
\text { ANDRADE }\end{array}$} \\
\hline & $\begin{array}{l}\text { Chega mais perto e contempla as } \\
\text { palavras. } \\
\text { Cada uma }\end{array}$ \\
$\begin{array}{l}\text { onde você estacionou, a porta } \\
\text { talvez abrisse, não houvesse } \\
\text { tantas chaves. }\end{array}$ & $\begin{array}{l}\text { neutra } \\
\text { e te pergunta, sem interesse pela } \\
\end{array}$ \\
& $\begin{array}{l}\text { resposta, } \\
\text { pobre ou terrível, que lhe deres: } \\
\text { Trouxeste a chave? }\end{array}$ \\
\hline
\end{tabular}

Fonte: Elaborado pelos dos autores (2021). 
O eu-lírico está em dúvida, usando o modo verbal do subjuntivo, da hipótese: "talvez abrisse" (v. 35), dúvida essa reforçada por uma sentença negativa: "não houvesse / tantas chaves" (v. 35-36). A dúvida, acompanhada pelo desejo de decifrar os sentidos encobertos da poesia, também está presente no poema de Drummond, mediante o que se infere da pergunta: "trouxeste a chave?".

Deslocando-se mais adiante no poema, observa-se um interessante recurso gráfico: o símbolo de parágrafo repetido três vezes " $\S \S \S ”(v . ~ 37)$, o que por si só já constitui um verso. O próprio símbolo parece um $s$, como a maior parte do poema, invocando a tendência concretista. Também pode lembrar uma onda sonora ou o símbolo da serpente, o pecado original, como é sugerido neste poema de Pedro Xisto:

\section{Imagem 1 - Epithalamium II, de Pedro Xisto}

\section{EPITHALAMIUM - II}

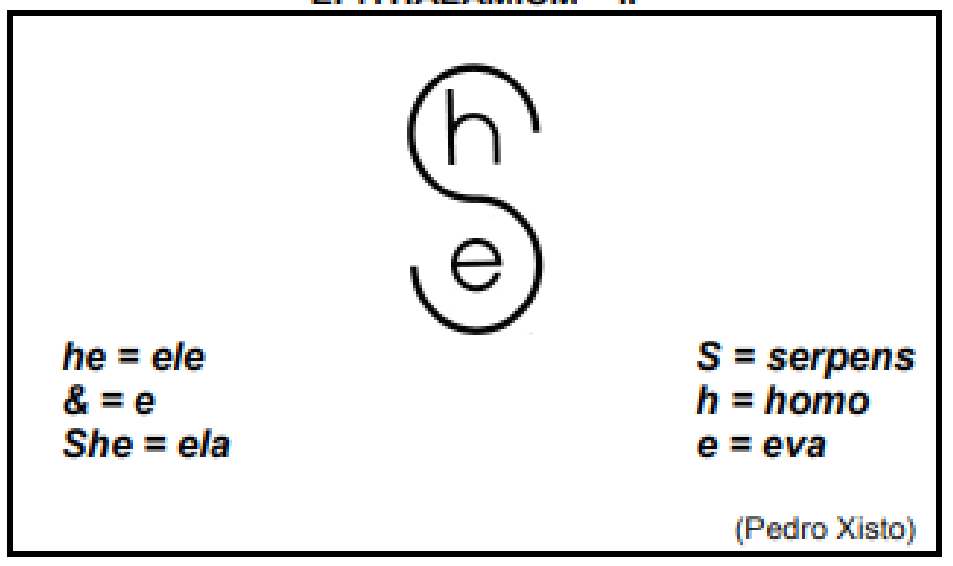

Fonte: Prova do Exame Nacional do Ensino Médio (ENEM) - 2004; banca Inep. 
O símbolo empregado no poema de Domeneck, ainda mais triplicado (noção mítica por si só, podendo remeter à Santíssima Trindade, por exemplo), é um símbolo da revisão, usado quando se quer indicar que em um determinado momento do texto deve haver paragrafação. Assim, ao mesmo tempo que é um recurso metalinguístico (a escrita se remetendo a ela própria, a seus próprios procedimentos) também configura mais uma manifestação do prosaísmo: a prosa invadindo o poema, inclusive graficamente, afinal, a poesia é canonicamente escrita em versos, e não em parágrafos. O método de edição e revisão assume caráter autobiográfico, haja vista o fato de Domeneck ter trabalhado como editor de revistas literárias e de coletâneas poéticas, o que remete novamente ao título do poema - ao (auto) retrato do artista -, que se encontra em uma relação orgânica com o todo. Outra abordagem sobre os recursos gráficos da revisão em obras literárias pode ser vista no romance contemporâneo História do cerco de Lisboa ([1989]/2013) do escritor português José Saramago. Nesse livro, o protagonista é, de fato, um revisor, e discute com o escritor acerca das mudanças no texto.

O revisor tem este notável talento de desdobrarse, desenha um deleatur ou introduz uma vírgula indiscutível, e ao mesmo tempo, aceite-se o neologismo, heteronimiza-se, é capaz de seguir o caminho sugerido por uma imagem, uma comparação, uma metáfora, não raro o simples som duma palavra repetida em voz baixa o leva, por associação, a organizar [...] (SARAMAGO, 2013, p. 22).

O deleatur é um sinal de revisão usado para indicar que a letra ou a palavra deve ser suprimida. Tal qual o símbolo do parágrafo no poema de Domeneck, o deleatur pode assumir uma função mais potente no texto, pois pode ditar ou modificar a 
ordem da história, visto que pode sugerir apagamento de palavras completas. Já o símbolo do parágrafo pode alterar a ordem ou o ritmo original do texto. E por falar em subversão, logo após os três sinais de parágrafo, em vez de "causa e consequência" está “causa e ausência” (v. 38). Ausência é o que falta, a falta psicanalítica, a incompletude do desejo, o rastro.

No próximo verso, a escrita se mostra cacofônica no verso "se se" (v. 39). Construção que pode parecer estranha, mas que é perfeitamente aceitável em língua portuguesa, considerando-se o primeiro "se" como conjunção integrante condicional e o segundo como pronome reflexivo. Para ser pronome, deveria haver um verbo em seguida, o que não ocorre. O que há é um substantivo, clivado (desdobrado) em vários adjuntos adnominais: "espera da voz" (v. 39-40) e "centro da garganta" (v. 40-42). Pode-se observar um procedimento semelhante no poema Meia lágrima (Quadro 4), da escritora brasileira contemporânea Conceição Evaristo:

\section{Quadro 4 - Comparação entre versos de Ricardo}

Domeneck e Conceição Evaristo

\begin{tabular}{|c|l|}
\hline RICARDO DOMENECK & \multicolumn{1}{c|}{$\begin{array}{c}\text { CONCEIÇÃO } \\
\text { EVARISTO }\end{array}$} \\
\hline se se & $\begin{array}{l}\text { Da língua cortada, } \\
\text { digo tudo, } \\
\text { amasso o silêncio } \\
\text { espera } \underline{\text { da }} \\
\text { voz o centro farfalhar do meio som } \\
\text { solto o grito do grito do } \\
\text { grito } \\
\text { e encontro a fala anterior, } \\
\text { aquela que emudecida }\end{array}$ \\
\hline
\end{tabular}

Fonte: Elaborado pelos autores (2021). 
A própria preposição "da" (de + a) pode gerar indeterminação, pois se o poema fosse pronunciado em voz alta, a depender da entonação e do contexto, poderia ser entendido “dá garganta” e não "da garganta”, isto é, em vez da preposição, o verbo "dar" conjugado na terceira pessoa do singular. O homoerotismo ergue-se de novo, junto com o membro: "e meu sexo / ergue-se / num esfregar de dedos" (v. 43-45). A expressão idiomática "num estalar de dedos" pode ser lida como um ato epifânico ou masturbatório, um lance de dedos ou de dados. Detalhe: o poeta faz questão de usar ênclise (pronome oblíquo ao fim do verbo; e o verbo "erguer" é pronominal, reflexivo, sendo que a ação se volta para o próprio eu-lírico). Em toda uma sequência, há a aliteração (repetição de sons consonantais; nesse

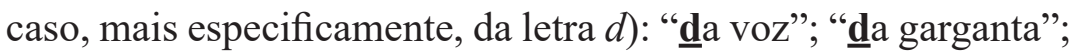
"de dedos"; "devo"; "ㄹeslize"; "do cerne". Lembrando que a aliteração é uma figura de linguagem de som (repetição de sons consonantais), e a musicalidade é importante para Domeneck, seja como tema, seja como matéria, como se depreende do título da obra na qual o poema está inserido, Sons: Arranjos: Garganta.

Após esse "esfregar de dedos", há uma ruptura: do erotismo volta-se para o cientificismo. $\mathrm{O}$ eu-lírico se sente em dívida com o italiano Galileu Galilei (v. 46), um dos nomes que remetem lado científico do eu-lírico, o qual busca entender as coisas com profundidade. Ora, tanto no amor quanto no poema, tenta-se vencer as aparências, dirigindo-se rumo à essência. E, nesse ponto, o flutuante eu-lírico supõe que a essência não é só abstrata, mas também concreta (científica, material, palpável). Essa alternância entre subjetivo e objetivo é uma das marcas do poema, que trabalha com o equilíbrio e também coma instabilidade de dicotomias. 
Da ciência, (co)pula-se para a filosofia, pois o eu-lírico atribui a "Wittgenstein" (v. 50) a aliterativa "seca do sêmen" (v. 51). Embora o mundo objetivo pareça sugar a subjetividade do indivíduo, não são vidas que são secas, como no romance da segunda geração modernista de Graciliano Ramos. Agora o sêmen (a semente) é seco. A "literaterra" é árida e inóspita, como a Terra devastada (2018) de T. S. Eliot. No entanto, o sêmen e as palavras podem voltar a jorrar de onde menos se espera: "do dicionário / como semântica" (v. 52-53). Assim como em A flor e a náusea, de Carlos Drummond de Andrade, presente em A rosa do povo: "É feia. Mas é uma flor. Furou o asfalto, o tédio, o nojo e o ódio." (ANDRADE, 2012, p. 14). Quer dizer, se é flor, pode resistir, nascendo até mesmo no asfalto, tamanha é sua resiliência. Não importa que seja feia, conquanto que seja flor. O mesmo ocorre com a poesia, especialmente com o Retrato de um artista quando Meridiano de Greenwich, que resiste, se desdobra e se adapta, mesmo convivendo com cientificismos e os consequentes esvaziamentos do sujeito e do mundo. "Poesia é risco" e força, porque é eco: "eco da fonte $\underline{\text { do }}$ eco" (v. 54), cuja clivagem mais uma vez lembra o poema de Conceição Evaristo. Esse eco ainda ressoa no verso subsequente, “‘.” (v. 55), pois no sinal de dois pontos, um ponto espelha (ou ecoa) o outro. $\mathrm{Na}$ língua portuguesa, essa pontuação pode assumir várias funções: introduzir explicações, enumerações, falas de personagens etc. No poema, esse recurso gramatical também é um elemento da disposição visual na página, que pode indicar ruptura. Além do mais, ao ocupar o lugar de um verso mesmo sem ser uma palavra, os “:” dialogam com o símbolo gráfico do parágrafo “§§§” (v. 37), que também é um dos versos do poema, apesar de não configurar um vocábulo. 
E o modernismo ecoa mais uma vez: "este desassossego / fora do lugar" (v. 56-57). Aqui, dois paralelos são possíveis: O livro do desassossego ([1982]/2006), de Fernando Pessoa, o único escrito pelo heterônimo Bernardo Soares, o único em prosa, ainda que poética. Outra referência é o livro As ideias fora do lugar ([1973]/2014), de Roberto Schwarz, no qual o crítico brasileiro discute a problemática da mera transposição de ideias eurocêntricas para o Brasil, sendo que a realidade histórica tupiniquim é outra. Assim, outro deslocamento do poema do poeta brasileiro pode ser percebido pelo constante embaralhamento das noções de centro e periferia: Portugal e Brasil, primeira e terceira pessoas, essência e aparência etc. O verso "O tremor da língua" (v. 58) remonta a essa continua mudança de posições, pois "língua" pode tanto ser a parte do corpo que gera o gozo pela cunilíngua quanto a linguagem compartilhada por brasileiros e portugueses.

$\mathrm{Na}$ sequência, o "ar" (v. 59), mais metafórico do que atmosférico, é descrito como "distraído" (v. 59). Esse ar "pulmões adentro" (v. 60) pode remeter à dinâmica do canto musical e a o resfolegar desejoso do sexo. O eu-lírico parece estar "sem resistência" (v. 61), em uma "passividade aérea" (v. 62), e oferecer-se como instrumento que cobiça ser tocado pelo amado. Mas o ar também permite deslocamento - "a rotação, a translação" (v. 64) -, assim como acontece no poema do paulista. Após esse momento de passividade, o eu-lírico sai da posição de resignação e volta a usar o "mas" (v. 65), conjunção coordenativa adversativa: "mas / não / o uso das condições / que deslocam a / fome" (v. 65-69). O enjambement corta o verso logo na palavra mais pungente, "fome", que é conotativa, podendo significar carência de alimento ou apetite sexual. 
Termos técnicos (da área médica) são empregados em seguida, assim como se nota na poesia cientificista pré-modernista de Augusto dos Anjos, destacadamente em seu poema Psicologia de um vencido (Quadro 5), presente no livro Eu ([1912]/1998):

\section{Quadro 5 - Comparação entre versos de Ricardo}

Domeneck e Augusto do Anjos

\begin{tabular}{|c|c|}
\hline RICA] & AUGUSTO DOS ANJOS \\
\hline $\begin{array}{l}\text { da fome } \\
\text { sabe a subnutricãa do } \\
\underline{\text { bulímico }}, \\
\text { e quando pensa-se poder } \\
\text { ao menos } \\
\text { confiar na assistência da } \\
\text { superfície, } \\
\text { contrai-se escabiose }\end{array}$ & $\begin{array}{l}\text { Eu, filho do carbono e do } \\
\text { amoníaco, } \\
\text { Monstro de escuridão e rutilância, } \\
\text { Sofro, desde a epigénesis da } \\
\text { infância, } \\
\text { A influência má dos signos do } \\
\text { zodíaco. } \\
\text { Profundissimamente } \\
\text { hipocondríaco, } \\
\text { Este ambiente } \\
\text { repugnância... } \\
\text { Sobe-me à boca uma ânsia análoga } \\
\text { à ânsia, } \\
\text { Que se escapa da boca de um } \\
\text { cardíaco. }\end{array}$ \\
\hline
\end{tabular}

Fonte: Elaborado pelos autores (2021).

Percebe-se o pessimismo decorrente da contração de uma doença: o sufixo "-ose" sugere patologia, advinda geralmente de doenças infecciosas. E o poema vai se infectando: por doenças, por gêneros textuais, por intertextualidades. O bulímico e o subnutrido entendem mais do conceito da fome do que o próprio dicionário. Não se pode confiar na "superfície" (v. 71): é preciso procurar o cerne, a essência das coisas.

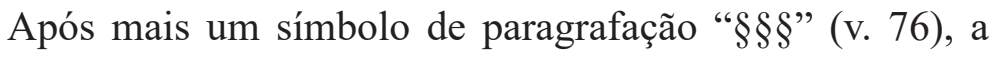
escrita já referida como cacofônica ("se se") agora se fragmenta 
em cacos: "mas quis dizer / a interrupção e / confundi-me na / expectativa do / constantemente jamais / atingido" (v. 7782). Uma sequência repleta de enjambements, cujos cortes ocorrem justamente nos conectivos, afastando o texto do sentido e remetendo-o à assemia da música instrumental. Ainda não saciado, o testeronado eu-lírico realiza outra incursão erótica após as locuções verbais "quis dizer" (v. 83) e "acredito poder" (v. 89). Ele crê que pode adivinhar (ou sentir) as ações do amado "no escuro" (v. 91), como no verso "pê-nis-e-Â-nus" (v. 93) (4 sílabas poéticas), composto por duas palavras paroxítonas que ritmam a escrita num jogo de tonicidade (sílabas fortes). Como disse Manoel de Barros, "tudo é matéria de poesia", ainda mais da contemporânea, como é o caso da escrita de Domeneck, que pode confrontar e abalar as convenções tradicionais: "pôde causar tamanho / estrago / nos valores / do meu mercado / interno" (v. 104-108).

No final, ao resistir ao desencantamento do mundo, o poema volta-se a si mesmo, para a primeira pessoa, pois é em si que encontra proteção e respostas confiáveis, ao passo que, no exterior, o que se encontram são cientificismos e desculpas. Em "o prejuízo / de minhas ilusões / de centro" (v. 121-123), depois de tantos deslocamentos entre elementos antagônicos, o eu-lírico parece situar o leitor em um centro, um meridiano literário, nunca livre de prejuízos e ilusões.

Pode-se, a partir desta análise, considerar Ricardo Domeneck um escritor atuante no contexto da poesia contemporânea, mas também um continuador do modernismo, não como conceito uno e estável, mas como fenômeno ainda potente e de caráter multivetorial que abarcou vários momentos, gêneros e vertentes em diferentes partes do mundo. Afinal, o poeta de Bebedouro, 
"bebeu" tanto do (es)copo de prosadores e poetas estrangeiros, como Joyce e Mallarmé, quanto de escritores nacionais, quer sejam pré-modernistas, quer sejam da primeira, segunda ou terceira gerações modernistas, como a historiografia literária didaticamente separa. Continuador, portanto, não de um ponto de vista progressista, como se houvesse um nexo causal entre o seu processo criativo e a literatura precedente levando a uma consequência necessária, no caso, a sua obra, mas como um autor que, em seu poema, ressignifica simultaneamente a criação atual e os diferentes projetos literários nele presentes. Esse efeito é alcançado pelo resgate (re)construtivo dessa pluralidade de movimentos e autores em uma poética que mescla referências autobiográficas, poesia visual, alusões, cortes, clivagens, interrupções e fragmentações que afastam o poema cada vez mais do sentido, ao menos de um sentido aparente. Cabe ao leitor o esforço de ir buscá-lo.

Uma das pistas para se guiar nesse labirinto é a intertextualidade do Retrato do artista quando Meridiano de Greenwich, a qual é uma das pontes que pode vincular (em um relacionamento aberto) o modernismo à literatura contemporânea, de tal forma que muitas vezes é possível entender o contemporâneo como modernismo continuado (ou ressignificado), ao menos como manifestação que, além de trazer um ponto de vista marcadamente autoral pela perspectiva autobiográfica do eu-lírico domeneckiano, atualiza técnicas e temas modernistas, mantendo-os profícuos na produção contemporânea. A pesquisa dessa relação, portanto, propicia tanto releituras dos modernismos, mantendo sua vitalidade criativa, quanto contribui para a apreensão crítica da produção literária da atualidade. 
Retrato da poesia contemporânea de Ricardo Domeneck quando em deslocamento com o modernismo

\section{Referências}

ANDRADE, Carlos Drummond de. A rosa do povo. São Paulo: Companhia das Letras, 2012.

ANDRADE, Oswald de. Poesias reunidas. Rio de Janeiro: Civilização Brasileira, 1971.

ANJOS, Augusto dos. Eu e outras poesias. 42. ed. Rio de Janeiro: Civilização Brasileira, 1998.

BANDEIRA, Manuel. Estrela da vida inteira. São Paulo: Círculo do Livro, 1998.

BARROS, Manoel de. Matéria de poesia. Rio de Janeiro: Alfaguara, 2019.

BECKETT, Samuel. Dante... Bruno. Vico... Joyce. In: NESTROVSKI, Arthur (org.). riverrun: ensaios sobre James Joyce. Rio de Janeiro: Imago, 1992. p. 323-338.

DOMENECK, Ricardo. Retrato do artista quando Meridiano de Greenwich. In: DOMENECK, Ricardo. Sons: Arranjos: Garganta. São Paulo: Cosac \& Naify; 7Letras, 2009. p. 63-67. (Coleção Ás de Colete).

ELIOT, T. S. Poemas. Tradução de Caetano W. Galindo. São Paulo: Companhia das Letras, 2018.

EVARISTO, Conceição. Poemas da recordação e outros movimentos. Belo Horizonte: Nandyala, 2008.

JOYCE, James. Finnegans Wake. Londres: Penguin, 1992.

JOYCE, James. Ulysses. Tradução de Caetano W. Galindo. São Paulo: Companhia das Letras, 2012.

JOYCE, James. Um retrato do artista quando jovem. Tradução de Caetano W. Galindo. São Paulo: Companhia das Letras; Penguin, 2016. 
MALLARMÉ, Stéphane. Um lance de dados. 2. ed. Tradução de Álvaro Faleiros. São Paulo: Ateliê Editorial, 2017.

MEIRELES, Cecília. Romanceiro da Inconfidência. São Paulo: Global, 2015.

MOISÉS, Massaud. Dicionário de termos literários. 12. ed. São Paulo: Cultrix, 2013.

PESSOA, Fernando. O livro do desassossego. São Paulo: Companhia das Letras, 2006. (Companhia de Bolso).

POESIA é risco. Intérprete: Augusto de Campos; Cid Campos. São Paulo: Sonopress Rimo Indústria e Comércio Fonográfica; SESC São Paulo, 2000. 1 CD.

RAMOS, Graciliano. Vidas secas. 140. ed. Rio de Janeiro: Record, 2019.

SARAMAGO, José. História do cerco de Lisboa. São Paulo: Companhia das Letras, 2013.

SCHWARZ, Roberto. As ideias fora de lugar. São Paulo: Companhia das Letras; Penguin, 2014. 